\title{
Astaxanthin for the Food Industry
}

\author{
Barbara Stachowiak ${ }^{1, *}$ and Piotr Szulc ${ }^{2}$ (D) \\ 1 Department of Technology of Plant Origin Food, Poznan University of Life Sciences, Ul. Wojska Polskiego 31, \\ 60-624 Poznan, Poland \\ 2 Department of Agronomy, Poznan University of Life Sciences, Ul. Dojazd 11, 60-632 Poznan, Poland; \\ piotr.szulc@up.poznan.pl \\ * Correspondence: barbara.stachowiak@up.poznan.pl; Tel.: +48-61-848-7361
}

check for

updates

Citation: Stachowiak, B.; Szulc, P. Astaxanthin for the Food Industry. Molecules 2021, 26, 2666. https:/ / doi.org/10.3390/molecules26092666

Academic Editor: Antonio Zuorro

Received: 28 March 2021

Accepted: 27 April 2021

Published: 2 May 2021

Publisher's Note: MDPI stays neutral with regard to jurisdictional claims in published maps and institutional affiliations.

Copyright: (c) 2021 by the authors. Licensee MDPI, Basel, Switzerland. This article is an open access article distributed under the terms and conditions of the Creative Commons Attribution (CC BY) license (https:// creativecommons.org/licenses/by/ $4.0 /)$.

\begin{abstract}
Xanthophyll astaxanthin, which is commonly used in aquaculture, is one of the most expensive and important industrial pigments. It is responsible for the pink and red color of salmonid meat and shrimp. Due to having the strongest anti-oxidative properties among carotenoids and other health benefits, natural astaxanthin is used in nutraceuticals and cosmetics, and in some countries, occasionally, to fortify foods and beverages. Its use in food technology is limited due to the unknown effects of long-term consumption of synthetic astaxanthin on human health as well as few sources and the high cost of natural astaxanthin. The article characterizes the structure, health-promoting properties, commercial sources and industrial use of astaxanthin. It presents the possibilities and limitations of the use of astaxanthin in food technology, considering its costs and food safety. It also presents the possibilities of stabilizing astaxanthin and improving its bioavailability by means of micro- and nanoencapsulation.
\end{abstract}

Keywords: astaxanthin; carotenoids; xanthophylls; antioxidants; bioactive compounds; Haematococcus pluvialis; Xanthophyllomyces dendrorhous; crustacean byproducts; encapsulation

\section{Introduction}

Astaxanthin (3,3'-dihydroxy- $\beta$-carotene- $4,4^{\prime}$-dione) is a carotenoid pigment without provitamin A activity in humans [1]. It is a xanthophyll with the chemical formula $\mathrm{C}_{40} \mathrm{H}_{52} \mathrm{O}_{4}$, molecular mass of $596.85 \mathrm{Da}$ and density of $1.081 \mathrm{~g} / \mathrm{L}$. Its Chemical Abstracts Service (CAS) number is 472-61-7. Astaxanthin was first isolated from lobsters in 1938 [2].

Astaxanthin is commercially used, mostly in the feed industry. At present, together with canthaxanthin, it is the most important and the most expensive pigment used in aquaculture for pigmentation of salmon, trout and shrimp meat (these animals do not synthesize astaxanthin de novo), which affects consumers' preferences around the world. Astaxanthin is a necessary component of the feed for aquarium fish as well as large ornamental fish. Scientific research has shown that the pigment has a positive influence on the color of egg yolk as well as the skin and meat tissue of broiler chicken carcasses. Due to strong anti-oxidative properties and other health benefits, astaxanthin is also used in the nutraceutical and cosmetic industries, and in some countries, it is occasionally used to fortify foods and beverages [3-6].

Chemical synthesis of astaxanthin is currently the most cost-effective, and thus its synthetic preparations have dominated over 95\% of the feed market [7]. The pharmaceutical, cosmetic and food industries use only natural astaxanthin. According to Grand View Research, the global astaxanthin market size was estimated at USD 1.0 billion in 2019. It is expected to witness a compound annual growth rate of $16.2 \%$ from 2019 to 2027 to reach USD 3398.8 million by 2027, owing to rising awareness of natural astaxanthin and its well-documented, multifunctional health benefits and safety [8].

This fact, as well as the coloring properties of the pigment, enable food technologists to design a sensorily attractive assortment of functional foods and active packages. There 
are two reasons why the use of astaxanthin in food technology is limited. As natural and synthetic astaxanthin differ in their structure, it is not certain how long-term consumption of synthetic astaxanthin may affect human health. The other reason is the few sources of natural astaxanthin and thus the high cost of obtaining it.

This review presents the possibilities and limitations to the use of astaxanthin in food technology. The article characterizes the structure, health-promoting properties and industrial use of astaxanthin. It gives an overview of industrial and potential sources of the pigment and considers costs and food safety. It also presents the possibilities of stabilizing astaxanthin and improving its bioavailability by means of micro- and nanoencapsulation.

\section{The Occurrence, Structure and Industrial Potential of Astaxanthin}

In nature, astaxanthin can be found in aquatic environments. It gives pink and red colors to the meat of fish such as Atlantic salmon, rainbow trout, Arctic char and red bream and to the shells of crustaceans such as krill, shrimp and lobster, etc. as well as the feathers of some wading birds, e.g., flamingo, scarlet ibis $[9,10]$. In the natural environment, the color of these animals is the result of bioconcentration of the pigment at consecutive trophic levels in the food chain [11]. In the aquatic environment, astaxanthin can be found in algae, which can synthesize this pigment, as well as in plankton crustaceans, which are capable of astaxanthin conversion from carotenoid precursors (chiefly from $\beta$-carotene and zeaxanthin). Thus, the color intensity of animal tissues mostly depends on the presence of astaxanthin in these animals' diets. This fact significantly influences the use of this pigment in the feed industry.

Like most carotenoids, astaxanthin is a 40-carbon tetraterpene consisting of linked isoprene units. The molecular structure of astaxanthin is composed of a linear polyene chain and two terminal $\beta$ rings (Figure 1) [12]. The system of 11 conjugated double bonds determines the pink and red color of astaxanthin (absorption maximum: in dimethyl sulfoxide (DMSO) $-492 \mathrm{~nm}$, in acetone $-477 \mathrm{~nm}$, in methanol $-477 \mathrm{~nm}$, in dimethylformamide$486 \mathrm{~nm}$, in chloroform-86 nm) and is responsible for its anti-oxidative potential [13]. Apart from that, both terminal rings of astaxanthin contain two polar function groups: hydroxyl $(\mathrm{OH})$ located at the two asymmetric carbons $\mathrm{C} 3$ and $\mathrm{C}^{\prime}$ and keto $(=\mathrm{O})$ at carbons C4 (Figure 1).

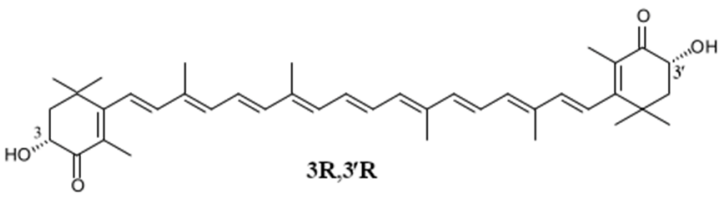<smiles>CC1=C(/C=C/C(C)=C/C=C/C(C)=C/C=C/C=C(C)/C=C/C=C(C)/C=C/C2=C(C)C(=O)C(O)CC2(C)C)C(C)(C)C=C(O)C1=O</smiles>

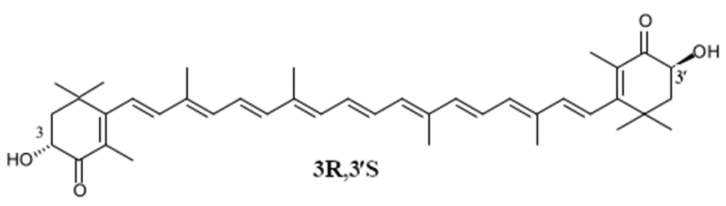

Figure 1. Configurational stereoisomers of astaxanthin.

The presence of these groups is typical of astaxanthin and makes it unique among other carotenoids. Thanks to the polar-non-polar structure, astaxanthin can fit the hydrophobic polyene carbon chain inside the bilayer lipid cell membrane, and its polar terminal rings can be located near its surface (Figure 2). In consequence, in comparison with other carotenoids, astaxanthin exhibits very high anti-oxidative activity in lipid systems [14]. 


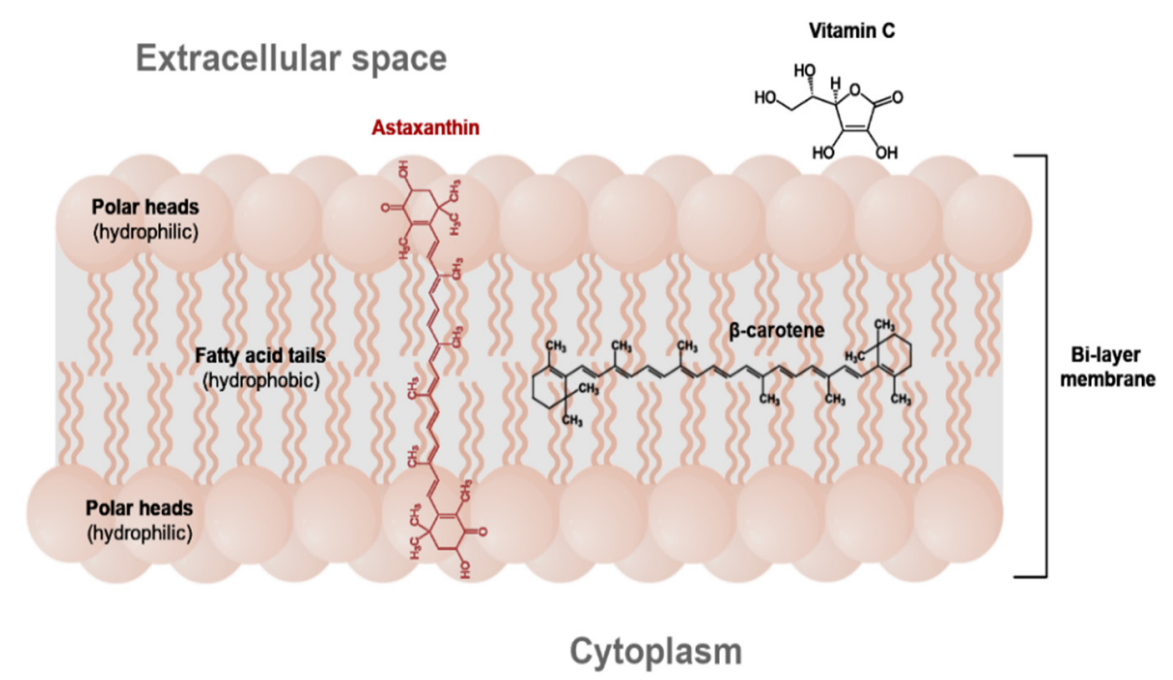

Figure 2. The location of astaxanthin and other antioxidants in the cell membrane (adapted from [15]).

Astaxanthin was found to protect membrane phospholipids and other lipids from peroxidation more effectively than $\beta$-carotene and lutein [16,17]. Its anti-oxidative activity is 10 and 100 times higher than that of $\beta$-carotene and vitamin $E$, respectively [18,19]. The outstanding anti-oxidative potential of astaxanthin has encouraged numerous investigations which indicated its potential clinical use in the prevention and treatment of diseases associated with reactive oxygen species such as cancers [20,21], neurodegenerative diseases [22-24], eye diseases (cataract, macular degeneration, asthenopia) [25,26], atherosclerosis and type 2 diabetes [15,27-29]. Astaxanthin counteracts gastric inflammations caused by Helicobacter pylori (chronic type B gastritis, peptic ulcer disease and gastric carcinoma) [30] and inflammations of the vocal folds [31]. It might be used to treat clinical sepsis [32]. It exhibits an immunomodulatory effect $[33,34]$. In contrast to $\beta$-carotene, astaxanthin easily permeates the blood-brain barrier as well as the blood-retinal barrier and prevents inflammations of these organs [12]. Astaxanthin may prevent photooxidative processes caused by UV radiation [17]. It improves the condition of men's and women's skin when administered orally. It reduces the depth of wrinkles, reduces age spot size and improves elasticity, skin texture, moisture content in the corneocyte layer and the corneocyte condition [35]. It is a bioactive component of cosmetics (creams, balms, oils, anti-aging serums), providing protection from solar radiation. Natural astaxanthin producers recommend a daily dose of $4-12 \mathrm{mg}$ for health benefits, which is similar to other carotenoids. The immunomodulatory effect was achieved in clinical trials when the daily dose of astaxanthin was 2 mg [33]. The EFSA Panel on Dietetic Products, Nutrition and Allergies recommends that the maximum daily dose of astaxanthin from alga Haematococcus pluvialis (AstaREAL supplements) should not exceed $4 \mathrm{mg}(0.06 \mathrm{mg} / \mathrm{kg}$ bw per day for a 70-kg person) [36]. Research has not shown that it is possible to overdose on astaxanthin. For example, Buesen et al. [37] did not observe any negative effects of the pigment when it was applied to rats at doses of $700-920 \mathrm{mg} / \mathrm{kg} / \mathrm{bw}$. Contrary to other antioxidants, astaxanthin never becomes a pro-oxidant [38].

Depending on the configuration of hydroxyl groups at the asymmetric carbons $\mathrm{C} 3$, different configurational isomers of astaxanthin can be formed: the (3R, $\left.3^{\prime} R\right)$ and $\left(3 S, 3^{\prime} S\right)$, which are enantiomers, and the meso form $\left(3 R, 3^{\prime} S\right)$ (Figure 1). Astaxanthin diastereoisomers differ in their physicochemical and biological properties as well as bioavailability. All of the aforementioned astaxanthin stereoisomers can be commonly found in nature. Their share depends on the source where they are found. The accumulation of astaxanthin isomers in aquatic animals is related to the isomer configuration of dietary astaxanthin (Table 1).

The presence of hydroxyl groups in benzoid rings enables esterification of astaxanthin. Esterified astaxanthin is more resistant to temperature fluctuations and photochemical 
reactions (photolysis, photosensitized oxidation) than free astaxanthin. In nature, astaxanthin can usually be found in the form of mono- and diesters, e.g., in algae and crustaceans' shells [39]. According to Snoeijs and Häubner [40], in natural zooplankton communities in the Baltic Sea, diesters prevailed during the cold season, but monoesters prevailed in the warm season. Astaxanthin can naturally be found in complexes with proteins or fats. The shells of lobsters, shrimps and other crustaceans contain a bright blue astaxanthin complex with a protein, i.e., crustacyanin. Only after thermal processing (after protein denaturation) is astaxanthin released, and the typical pink color can be seen. The dark green color is astaxanthin lipoglycoprotein, present in lobster ovaries and eggs. Ovorubin is a complex of astaxanthin ester with glycoprotein that gives the red color to the eggs of channeled apple snails (Pomacea canaliculata) [41].

Table 1. Astaxanthin sources in nature and its configurational isomers.

\begin{tabular}{ccccc}
\hline \multirow{2}{*}{ Astaxanthin Source } & \multicolumn{3}{c}{ Configurational Isomer [\%] } & References \\
\cline { 2 - 5 } & $\mathbf{3 S}, \mathbf{3}^{\prime} \mathbf{S}$ & $\mathbf{3 R}, \mathbf{3}^{\prime} \mathbf{R}$ & Meso Form & \\
\hline Xanthophyllomyces dendrorhous (yeast) & - & 100 & - & {$[42]$} \\
Hematococcus pluvialis (algae) & 100 & - & - & {$[43]$} \\
Petels of Adonis spp. & 100 & - & - & {$[44,45]$} \\
Crustacyanine (lobster) & 33 & 39 & 28 & {$[39]$} \\
Pandalus borealis (shrimp) & $12-25$ & - & $50-53$ & {$[39]$} \\
Atlantic/Pacific salmon & $78-85$ & $12-17$ & $2-6$ & {$[39]$} \\
\hline
\end{tabular}

Long thermal processing, even at low temperature, promotes the hydrolysis of esterified astaxanthin and yields free astaxanthin. This fact is very important during the production of smoked salmonoids and dried salted shrimp. Studies showed that the astaxanthin content in cooked shrimp decreased by $78 \%$ after four days of direct sun drying due to photodegradation [46]. The content of this pigment was much lower than the content obtained in a jet-spouted bed-drier at 80,100 and $120^{\circ} \mathrm{C}$ [47].

Apart from pigmentation of animal organisms, like other carotenoids, astaxanthin has other metabolic and physiological functions. It has a positive influence on the growth and reproduction of crustaceans [48], sea urchins (Pseudocentrotus depressus) [49], guppies (Poecilia reticulata) [50] and salmonids. A positive effect of astaxanthin supplementation on the reproductive traits of rainbow trout was found. In this case, the astaxanthin content in the eggs and the fertilization rate, the percentage of eyed eggs and hatching were significantly correlated [51]. Studies have shown that astaxanthin supplementation contributes to the health of laying hens by influencing the activity of antioxidant enzymes as well as anti-inflammatory and immunomodulating interleukins. Astaxanthin improves superoxide dismutase (SOD) and glutathione peroxidase (GSH-Px) activities and diminishes malondialdehyde (MDA) content in both the liver and serum. Additionally, astaxanthin alleviates interleukin 2, 4, and 6 (IL-2, IL-4 and IL-6, respectively) in serum [52].

\section{Commercial Sources of Astaxanthin}

\subsection{Chemical Synthesis}

There are a lot of advantages of the chemical synthesis of carotenoid pigments, e.g., it is possible to obtain pigments of desired purity and consistency. However, as a consequence, mixtures of stereoisomers are produced. Some of them cannot be found in nature. Therefore, they may not exhibit activity identical to natural carotenoid isomers. They may exhibit different activities from natural carotenoids and cause local adverse effects [53]. It is noteworthy that astaxanthin synthesized in nature occurs in the trans form (3S, 3S), whereas synthetic astaxanthin is a mixture of two optical isomers and the meso form at a ratio of 1:2:1 (3R, $\left.3^{\prime} R\right),\left(3 R, 3^{\prime} S\right)$ and $\left(3 S, 3^{\prime} S\right)$ (Figure 1) [54]. As farm animals are fed with synthetic astaxanthin, it is easy to determine their origin by analyzing the composition of the pigment. 
Until now, chemical synthesis has been the cheapest method of obtaining astaxanthin because it does not consume much energy and emits small amounts of greenhouse gases. The cost of production of $1 \mathrm{~kg}$ of synthetic astaxanthin is estimated at about 1000 dollars, whereas its market value is higher than 2000 dollars. $1 \mathrm{~kg}$ of the natural pigment obtained from Xanthophyllomyces dendrorhous yeasts costs 2500 dollars, whereas $1 \mathrm{~kg}$ of astaxanthin from Haematococcus pluvialis algae costs 7000 dollars [55]. Natural astaxanthin is characterized by higher oxygen radical absorbance capacity, higher stability and better assimilability. This difference results from the presence of astaxanthin stereoisomers in synthetic preparations $[56,57]$. For this reason, at present, only natural astaxanthin can be a component of dietary supplements for humans.

The oldest strategy for chemical synthesis of astaxanthin involves the Wittig reaction of two appropriate C15-phosphonium salts with a symmetrical C10-dialdehyde as a central building block [58]. Nguyen [59] also lists other strategies: cantaxanthin hydroxylation, $\mathrm{C} 10+\mathrm{C} 10+\mathrm{C} 10$ synthesis via dienol ether condensation and isomeration of lutein extracted from marigold to astaxanthin.

In the early 1980s, Hoffmann La Roche (Basel, Switzerland) developed and manufactured the first synthetic astaxanthin preparation under the trade name CAROPHYLL ${ }^{\circledR}$ Pink $\left(C^{\circledR} \mathrm{P}\right)$. In $C^{\circledR} \mathrm{P}$, sensitive astaxanthin molecules are stabilized with antioxidants and embedded in a carbohydrate and gelatin matrix. This stable product is coated with starch to improve handling. According to the manufacturer's declaration, $\mathrm{C}^{\circledR} \mathrm{P}$ contains $10 \%$ astaxanthin. In 2002, Hoffmann La Roche sold the production rights to DSM (Denmark), who developed CAROPHYLL ${ }^{\circledR}$ Stay-Pink $\left(\mathrm{C}^{\circledR} \mathrm{SP}\right)$, containing about $11 \%$ astaxanthin dimethyl succinate. Orally administered, it is hydrolyzed and converted to free astaxanthin in the intestines of fish and then absorbed, metabolized and distributed in the same manner as free astaxanthin. The purpose of $C^{\circledR} S P$ is to provide farmed Atlantic salmon (Salmo salar) and rainbow trout (Oncorhynchus mykiss) with a source of the carotenoid astaxanthin, which gives the characteristic pink color to wild salmonids.

Lucantin ${ }^{\circledR}$ Pink (BASF Chemical Company, Ludwigshafen, Rhineland-Palatinate, Germany) is another synthetic astaxanthin preparation that contains at least $10 \%$ astaxanthin. It is used for efficient pigmentation of shrimp, salmon, egg yolks and broiler skins.

In May 1995, the Food and Drug Administration (FDA) permitted the use of synthetic astaxanthin as a pigment in animal and fish feeds [60]. In the European Union, synthetic astaxanthin was registered as $2 \mathrm{a} E 161 \mathrm{j}$. The use of synthetic astaxanthin for feeding salmon, trout, shellfish and ornamental fish is permitted without expiry date. The dose of the pigment cannot be higher than $100 \mathrm{mg} / \mathrm{kg}$ of the total mixed ration (moisture content $12 \%$ ) [61].

Apart from that, the EU Commission Regulation (EC) No. 393/2008 permits the use of astaxanthin dimethyldisuccinate (2a(ii) 165) as a feed additive for salmon and trout [62]. In July 2020, the European Commission renewed the authorization of astaxanthin dimethyldisuccinate as a feed additive for fish and crustaceans and repealed Regulation (EC) No. 393/2008 [63].

The EU Regulation (EC) No. 1925/2006 on the addition of vitamins, minerals and other substances to foods does not permit the use of synthetic astaxanthin in food [64]. Nor does it have GRAS status (Generally Recognized as Safe) in the US.

These legal restrictions were introduced because of the differences between natural and synthetic astaxanthin, as the latter might be harmful to humans and the environment. A cause and effect relationship has not been established between the consumption of astaxanthin and the maintenance of normal joints, tendons or connective tissue; protection of DNA proteins or lipids from oxidative damage; maintenance of normal visual acuity; and maintenance of normal blood cholesterol concentrations or maintenance of low plasma concentrations of CRP (C Reactive Protein) [65]. 


\subsection{Natural Systems as a Source of Astaxanthin}

Astaxanthin is obtained from primary sources such as higher plants; microscopic phytoplankton algae Haematococcus pluvialis [2], Chlorella zofingiensis, Chlorococcum sp. [66]; and some microorganisms, i.e., Xanthophyllomyces dendrorhous (anamorph Phaffia rhodozyma) yeasts and bacteria such as Mycobacterium lacticola, Brevibacterium, Agrobacterium aurantiacum, Alcaligens sp. strain PC-1. and Paracoccus carotinifaciens $[10,67]$. The industrial production of natural astaxanthin started in the 1980s. Cynotech Corporation (Kona, HI, USA) is the oldest and largest producer of the pigment from microalgae. The trade name of the product is BioAstin ${ }^{\circledR}$. It is oleoresin extracted from Haematococcus pluvialis. It includes a minimum of 4 milligrams of astaxanthin per gel cap. In China, astaxanthin in industrial production is extracted from krill and crustacean byproducts.

\subsubsection{Astaxanthin from Plant Systems}

Species of the Adonis genus, i.e., A. aestivalis and A. annua (Figure 3a), are the richest sources of astaxanthin. According to Cunningham and Gantt [68], this pigment makes up about $1 \%$ of the dry matter of petals of these plants.

\section{(a) Adonis aestivalis}

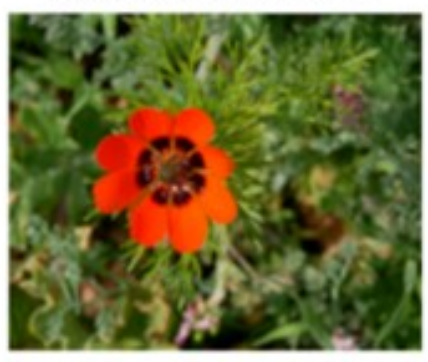

(b) Haematococcus pluvialis (algae)

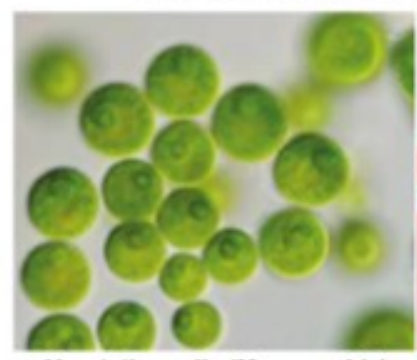

Vegetative cells (Macroozoids)

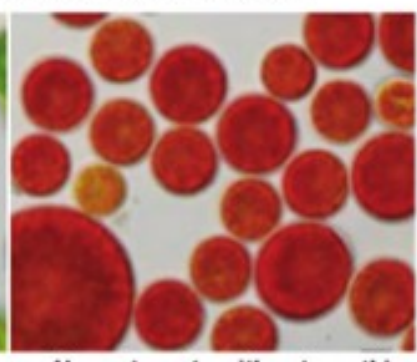

Haematocysts with astaxanthin

\section{(c) Xanthophyllomyces dendrorhous (yeast)}

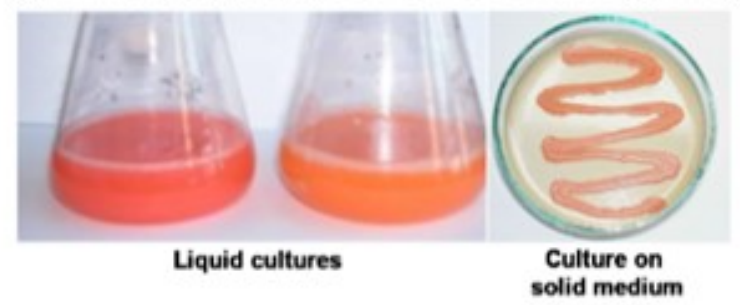

Figure 3. Natural sources of astaxanthin; (a) Adonis plants, (b) photo of H. pluvialis alge, (c) was adapted from [69].

However, due to the low yield of flower biomass from the cultivation area, this plant is not a cost-effective source of the pigment. Early studies on using Adonis species as industrial sources of astaxanthin concerned the obtaining of cultivars with a larger number of petals in the flower head [70]. Later studies concerned the isolation of genes encoding the astaxanthin biosynthesis pathway from Adonis plants and their transfer to other plants, e.g., marigolds, which guaranteed a high yield of biomass with carotenoids [71]. As the synthesis of carotenoids depends on the content of precursors and the possibility of converting them in the conversion pathway, researchers became particularly interested in plants that can produce large amounts of $\beta$-carotene, such as marigolds, various oil palm species, canola rapeseed, sweet potatoes and maize because it is possible to insert DNA fragments responsible for the conversion of $\beta$-carotene into astaxanthin from Adonis plants into the genome of these plants [72,73]. Typically, the biosynthesis of astaxanthin from $\beta$-carotene requires ketolase and hydroxylase to add carbonyl and hydroxyl at positions 4 and 3 of each terminal $\beta$-ionone ring, respectively. Researchers successfully produced transgenic tomatoes with a high concentration of free astaxanthin in leaves $(3.12 \mathrm{mg} / \mathrm{g})$ and 
its esterified form in fruit $(16.1 \mathrm{mg} / \mathrm{g})$. The success was achieved through co-expression of two genes from microalgae, i.e., $\beta$-carotene ketolase from Chlamydomonas reinhardtii and $\beta$-carotene hydroxylase from Haematoccocus pluvialis [74]. There are also studies on genetic modification of marigolds (Tagetes) and their use as a source of astaxanthin for feeding animals [75].

\subsubsection{Microbiological Synthesis of Astaxanthin}

At present, microbiological synthesis of astaxanthin is one of the most intensely developing research areas. It has more advantages than plant production. It is easy to culture microorganisms, which grow fast on cheap culture media. Their development does not depend on weather conditions, and the shade of the pigment is stable [76]. However, the use of microbial systems for astaxanthin production is not very economical. The pigment is an intracellular metabolite. Therefore, the cost of biosynthesis depends on the cost of biomass production, the concentration of the pigment in cells, the metabolic activity of the cells producing the pigment and the need to isolate the pigment from the cells and purify it [53].

Haematoccocus pluvialis freshwater microalgae are a basic source of natural astaxanthin on the market. They accumulate up to $4 \%$ of the pigment in dry biomass. It is the highest natural concentration of astaxanthin. The predominant form of astaxanthin in H. pluvialis is monoester [2]. Researchers stress the fact that it is particularly difficult to breed microalgae in open systems, e.g., in ponds, due to the risk of contamination with unwanted species of algae, bacteria, fungi, etc. For this reason, it is necessary to use expensive, high-capacity photobioreactors [77]. Another problem is that Haematoccocus pluvialis grow slowly, and their yield of biomass is low when they are grown on traditional media. Apart from that, they accumulate astaxanthin only when they are exposed to environmental stress, i.e., a nitrogen or phosphorus deficit, the presence of salicylic acid and ethanol, high salinity of the growth medium or intensive light $[2,78,79]$. In such cases, they form immotile thick-walled hematocysts that contain the pigment (Figure 3b). Thirdly, in order to isolate astaxanthin from hematocysts, it is necessary to disintegrate the thick cell wall. All these procedures make astaxanthin very expensive. Its production is limited to specialized markets, chiefly the pharmaceutical market. Astaxanthin is produced from Haematoccocus pluvialis microalgae in the United States, Japan and India [80]. It is a component of vitamin preparations, dietary supplements and protective creams. It is also used in organic farming. In 2014, the EFSA Panel on Dietetic Products, Nutrition and Allergies of the European Commission issued a positive opinion about the safety of astaxanthin-rich ingredients of AstaREAL preparations made from Haematoccocus pluvialis. According to the opinion, their consumption was not considered to be nutritionally disadvantageous and there were no safety concerns regarding genotoxicity [36]. In December 2017, astaxanthin-rich oleoresin from Haematococcus pluvialis algae was on the European Commission list of novel foods [81]. H. pluvialis cultivation can be carried out both in closed systems exposed to the sunlight or strictly controlled lighting, or in open ponds. Supercritical fluid extraction (SFE) is used to remove astaxanthin oleoresin from dried algal cells with supercritical $\mathrm{CO}_{2}$ or ethyl acetate as solvents The technique for SFE is described below. The astaxanthin is diluted in edible oils such as olive oil, safflower oil, sunflower oil or MCT (Medium Chain Triglycerides) at six levels: $2.5 \%, 5.0 \%, 7.0 \%, 10.0 \%, 15.0 \%$ and $20.0 \%$. These preparations are intended to be used in fermented and non-fermented liquid dairy products, fermented soya products and fruit drinks for healthy adults [36].

For many years, scientific researchers and industrial producers have been particularly interested in red Xanthophyllomyces dendrorhous yeasts (Figure 3c), which synthesize unesterified astaxanthin, predominantly in the $\left(3 R, 3 R^{\prime}\right)$ form, which is different from that of Haematoccocus pluvialis algae. It is concentrated with other carotenoids in lipid droplets suspended in the cytoplasm or in cytoplasmic membranes in the lipid layer (it is not visible in microscopic studies). This form is very stable [82]. 
Studies indicated that unesterified astaxanthin was more efficiently taken up and utilized for pigmentation in rainbow trout than astaxanthin dipalmitates, probably due to the limited capacity of intestinal esterases to hydrolyze these esters [83]. It is particularly important because inactivated yeast biomass can be a ready product, which is not only rich in assimilable astaxanthin, but also necessary nutrients-proteins, lipids and B vitamins [11].

Low cellular concentration of astaxanthin is an essential problem while using Xanthophyllomyces dendrorhous yeasts for industrial production of the pigment. The content of astaxanthin in wild strains ranges from 0.01 to $0.03 \%$ of dry matter. As the cellular concentration of the pigment is so low, it is necessary to add a few percent of yeast to feeds so as to give the right color to salmon or trout meat. However, it is not advisable in aquaculture due to the high content of polysaccharides in the yeast cell walls [84]. Only the Xanthophyllomyces dendrorhous strains capable of astaxanthin synthesis 5- to 10-fold higher than in wild strains may be used for industrial production of the pigment and greatly reduce its market price [82,85]. Such strains can be obtained with chemical mutagenesis [86] or with a combination of classical mutagenesis and genetic pathway engineering $[87,88]$.

\subsubsection{Crustacean Byproducts}

Inedible parts of shrimp, crabs and other crustaceans, i.e., heads, shells, tails, etc., can be used as sources of natural astaxanthin in aquaculture. According to Mezzomo et al. [89], the annual worldwide capture of marine crustaceans was 3.2 million tons. Inedible byproducts made up $40-56 \%$ of the raw material weight, depending on the species, size and shelling procedure $[90,91]$. Non-polar solvents and vegetable oil are routinely used for industrial extraction of carotenoids, including astaxanthin, from crustacean byproducts. The choice of solvent is very important because it affects the astaxanthin extract quality. The solvent must be non-flammable, non-toxic, non-volatile and effective at low temperatures. Sunflower, groundnut, coconut and rice bran oils seem to be the most adequate. In recent years, flaxseed oil has gained considerable attention as a potential astaxanthin extractant due to the high content of omega-3 acids, i.e., alpha-linolenic acid and linoleic acid [92]. These acids have been shown to provide protection against cardiovascular disease and inflammation. Dispersed natural astaxanthin in flaxseed oil may provide healthier food options for consumers. Pu et al. [91] indicated that astaxanthin extracted from shrimp byproducts by means of flaxseed oil effectively protected the fatty acids it contained from oxidation during heating from 40 to $60{ }^{\circ} \mathrm{C}$ for $4 \mathrm{~h}$. Nevertheless, the rate of astaxanthin degradation in flaxseed oil was significantly influenced by temperature. Astaxanthin was stable in flaxseed oil only at 30 and $40{ }^{\circ} \mathrm{C}$ but exhibited substantial degradation at 50 and $60{ }^{\circ} \mathrm{C}$. In the near future, astaxanthin preparations in flaxseed oil may become as popular as krill oil (e.g., Gold Krill, Mega Red Omega 3, Krill Oil), which is a source of astaxanthin and omega-3 acids. These preparations are recommended to prevent atherosclerosis, cardiovascular, eye and neurodegenerative diseases caused by aging [91].

Higher efficiency of astaxanthin extraction from crustacean byproducts can be achieved by using organic solvents such as chlorinated ones. However, they are toxic and potentially carcinogenic. On the other hand, solvents used for industrial production such as $n$-hexane, $n$-heptane, acetone, methanol and petroleum ether require high temperatures, affecting thermolabile astaxanthin. Otherwise, the pigment extraction efficiency is low [90,93].

Supercritical fluid extraction (SFE) can be used as an alternative to conventional techniques of carotenoid extraction from crustacean byproducts. The use of nonpolar supercritical carbon dioxide $\left(\mathrm{SC}-\mathrm{CO}_{2}\right)$ as the solvent is the most commonly employed in SFE for extracting low-polarity and heat-sensitive bioactive compounds due to its low critical properties ( $\mathrm{Tc}=31.1^{\circ} \mathrm{C} ; \mathrm{Pc}=73.8$ bar) [94]. $\mathrm{SC}-\mathrm{CO}_{2}$ is chemically inactive, available, economical and non-toxic. It is not necessary to remove the solvent when $\mathrm{CO}_{2}$ is used in a supercritical state because this gas is at a normal temperature and atmospheric pressure. Apart from that, $\mathrm{CO}_{2}$ has GRAS status, and it is not expensive [89,90]. Currently, $\mathrm{SC}-\mathrm{CO}_{2}$ is the most modern and effective method of obtaining essential oils, polyunsaturated oils, 
phytosterols, carotenoids, flavonoids and anthocyanins [95]. Sánchez-Camargo et al. [90] extracted astaxanthin from freeze-dried red spotted shrimp (Farfantepenaeus paulensis) waste (including the head, tail and shell) using SC-CO $\mathrm{CO}_{2}$ and evaluated the effects of the extraction conditions of pressure (200-400 bar) and temperature $\left(40-60{ }^{\circ} \mathrm{C}\right)$ on the total extraction yield, astaxanthin extraction yield and astaxanthin concentration in the extract. It was shown that temperature, and especially pressure, had a significant effect on the astaxanthin extraction yield. The highest amount of the extract (with 39\% astaxanthin recovery) was obtained at $43^{\circ} \mathrm{C}$ and 370 bar. At low pressures, an increase in temperature resulted in a decrease in the amount of astaxanthin extracted.

Mezzomo et al. [89] studied SFE efficiency in order to concentrate carotenoids from pink shrimp (Penaeus brasiliensis and Penaeus paulensis) processing waste (composed essentially of head, carapace). The process efficiency was studied by the effects of the operational conditions and co-solvents, hexane:isopropanol solution (50:50, $v / v)$ and sunflower oil (as co-solvents mixed to the supercritical $\mathrm{CO}_{2}$ in concentrations of 2 and $5 \%(w / w)$ ). The highest astaxanthin yield was obtained with $\mathrm{SC}-\mathrm{CO}_{2}$ at 300 bar and $60^{\circ} \mathrm{C}$. Although the use of hexane:isopropanol solution in SFE was successful to enhance the extraction yield compared to SFE with SC- $\mathrm{CO}_{2}$, the system selectivity did not increase carotenoid concentration. The authors of both studies indicated that carotenoid extraction increased along with $\mathrm{CO}_{2}$ density. The pigment extraction efficiency was lower at lower pressures and higher temperatures.

However, there are some limitations to the use of crustacean byproducts as a basic source of astaxanthin for aquaculture. Apart from the seasonal availability of crustacean byproducts (e.g., in Asian countries), the high costs of their storage and the need to protect them from decay (usually by mild lactic acid fermentation or with organic acids), these byproducts have a low content of astaxanthin-about $0.15 \%$. Therefore, their content in feeds must be high (10-25\%) to achieve adequate color of animal tissues. Unfortunately, they contain large amounts of water, ash and chitin, which limit their quantitative share in feed [2]. Additionally, even low concentrations of organic acids used for preservation cause the conversion of astaxanthin monoesters into diesters and reduce the amount of carotenoids recovered from byproducts. However, Sachindra et al. [96] indicated that lactic acid fermentation reduced the amount of solvent (organic compound or vegetable oil) used for the isolation of carotenoids from shrimp byproducts.

\section{Methods of Astaxanthin Stabilization and Improvement of Its Bioavailability}

Humans usually consume synthetic astaxanthin in seafood including farmed salmonids and shrimp. Food producers are particularly interested in astaxanthin due to its antioxidative potential and attractive color. The supplementation of astaxanthin in food might be a practical and beneficial health management strategy. The following products are mostly taken into consideration: fermented and non-fermented liquid dairy products, fermented soya products and fruit drinks for healthy adults at a maximum level of $1.6 \mathrm{mg}$ astaxanthin per $100 \mathrm{~g}$ or $100 \mathrm{~mL}$ [36].

Apart from the price, there are two reasons why the use of natural trans astaxanthin in the food industry is limited. Firstly, it is unstable during isolation, manufacture and storage. Due to the highly unsaturated structure of astaxanthin, it can be easily damaged under adverse conditions of the technological process, e.g., acidic environments, heat, light, transition metal ions, singlet oxygen and free radicals, especially after being removed from its biological matrix [36]. This can cause the loss of its desirable nutritive and biological properties as well as the production of undesirable flavor and aroma compounds. The other serious problem which limits industrial use of astaxanthin is its poor solubility in water $(83 \mathrm{mg} / \mathrm{L})$ as well as its limited solubility in lipid blood components, e.g., triglycerides. As a consequence, astaxanthin is characterized by very low bioavailability, similar to other functional lipophilic nutrients [97]. As the solubility of bioactive compounds determines their bioavailability, the slow dissolution or solubilization of functional lipophilic nutrients in aqueous-based systems results in their low absorption rate and their low bioavailabil- 
ity [98]. For this reason, there has been research on the production of hydrophilic stable and bioactive derivatives of the pigment, e.g., various esters of astaxanthin such as disodium disuccinate astaxanthin, tetrasodium diphosphate astaxanthin and various fatty acid esters of astaxanthin [99-101].

The introduction of astaxanthin and other carotenoids into aqueous food systems and other complex environments usually causes the formation of oil-in-water $(\mathrm{O} / \mathrm{W})$ emulsion. Another step involves protecting the dispersion of astaxanthin from molecular modification and destruction. Many studies indicate that high stability, water solubility and high bioavailability of astaxanthin dispersion can be easily achieved by encapsulation technologies - microencapsulation and nanoencapsulation systems. In order to achieve the encapsulation of bioactive food compounds, polymer carriers are usually used. They should be compatible with the product's properties (flavor, texture, shelf life), biodegradable and easy to use.

Proteins, especially milk proteins, are good emulsifiers, and hence, they are utilized as ingredients in a wide range of formulated food emulsions. Anarjan et al. [102] used sodium caseinate to stabilize astaxanthin nanodispersion. Dispersions were prepared using an emulsification-evaporation technique. The researchers obtained a preparation with optimal physicochemical properties (average particle size, polydispersity index, minimal loss of astaxanthin during the process). Astaxanthin nanoemulsion was prepared by three passes through a high-pressure homogenizer at $30 \mathrm{MPa}$. Next, the organic solvent (dichloromethane) was removed from the system by evaporation at $25^{\circ} \mathrm{C}$.

Shen and Quek [103] suggested using spray-drying technology to produce highquality encapsulated astaxanthin that could be used in food systems. Encapsulation with spray-drying technology consists of homogenization of lipophilic core materials in a solution containing wall material to form a stable emulsion. Next, the emulsion is fed into a spray dryer, where it is converted into dry powders. Researchers have also used natural emulsifiers accepted by consumers, whey protein isolate and sodium caseinate, with soluble corn fiber as wall systems. The core material contained sunflower oil and the commercial astaxanthin preparation Cyanotech Bioastin. After homogenization and spraydrying of the emulsion, the powdered, encapsulated astaxanthin preparation was characterized by acceptable properties including water activity, surface morphology and oxidative stability. The microencapsulation efficiency was high ( 95\%) for both types of wall systems, indicating the suitability of these hydrophilic wall matrices for the encapsulation of hydrophobic astaxanthin.

Polysaccharides and their derivatives have also received great acceptance from the pharmaceutical and food industries as emulsion stabilizers due to their safety, biodegradability, biocompatibility and non-toxicity. Higuera-Ciapara et al. [104] obtained a thermostable astaxanthin preparation (within a temperature range of $25-45^{\circ} \mathrm{C}$ during eightweek storage) that was characterized by good solubility. They applied microencapsulation of the pigment emulsion in a chitosan matrix cross-linked with glutaraldehyde, using the method of multiple emulsion/solvent evaporation. Cyclodextrins (CDs) are cyclic oligosaccharides (oligodextrins) obtained by the enzymatic breakdown of starch. They consist of various numbers of glucopyranose residues, linked together by $\alpha$-1,4-glycosidic bonds in order to form a toroidal ring shape, with well-established use as encapsulating agents. The inner surface of the taurus is hydrophobic. The outer surface is hydrophilic, which makes the CDs well-soluble in water. Due to their molecular structure, CDs form stable inclusion complexes (host-guest complexes) with many molecules and organic compounds. The best-known CDs are $\alpha-C D, \beta-C D$ and $\gamma-C D$, which are composed of 6,7 and 8 glucopyranose units, respectively [94]. CDs differ in internal diameter and are therefore characterized by selectivity of complexation. Among them, the most important in terms of practical use is $\beta-C D$, and its derivatives grade improve the water solubility of lipophilic small molecules, including carotenoids, and are widely used to prepare encapsulated substances in food and pharmaceutical applications [105]. Chen et al. [97] showed that in comparison with native astaxanthin, the stability of the inclusion complex of astaxanthin with $\beta-C D$ 
(1:4) against temperature and light was greatly enhanced, but its aqueous solubility was only slightly enhanced $(<0.5 \mathrm{mg} / \mathrm{mL})$. Yuan et al. [106] obtained an inclusion complex of astaxanthin with hydroxypropyl- $\beta$-cyclodextrin (HP- $\beta-\mathrm{CD})$ that was characterized by high astaxanthin solubility $(>1.0 \mathrm{mg} / \mathrm{mL})$. HP- $\beta-C D$ protected astaxanthin from thermal degradation up to $40^{\circ} \mathrm{C}$. The complexation of crystalline astaxanthin with a derivatized form of $\beta$-CD and a solubilizing agent, Captisol ${ }^{\circledR}$ (sulfobutyl ether $\beta$-cyclodextrin (sodium)), increased the water solubility of astaxanthin by approximately 71-fold to a concentration of $2 \mu \mathrm{g} / \mathrm{mL}$ [101]. According to Lancrajan et al. [107], carotenoid incorporation into a $\beta$-cyclodextrin carrier was more efficient than liposomal delivery or traditional methods of dissolving the carotenoid in an organic solvent such as tetrahydrofuran (THF), ethanol, dichloromethane or chloroform. The potential breakdown of cyclodextrin to individual sugar moieties is less toxic to humans than organic solvents.

At present, the largest number of studies concern the incorporation of astaxanthin in a nanodispersion system. Nanodispersion systems seem to be useful in many food and pharmaceutical applications because of their high stability, water solubility and high bioavailability as well as their ease of processing [108]. There is no clear definition of the term 'nano' as applied to foods. By reducing the particle size below a certain threshold value, the resulting material exhibits physical and chemical properties (color, solubility, chemical reactivity and toxicity) that are significantly different from those observed in their macroscopic counterparts. Thus, the scale of particle size reduction determines its applicability. Therefore, it is difficult to define the upper range of the nanostructure size. Many scientific publications use the term 'nano' to describe structures of about several hundred nanometers (instead of strictly $100 \mathrm{~nm}$ ) [109]. The European Commission recommends that the term nanomaterial should be used for a material containing particles in an unbound state or as an aggregate or agglomerate and where, for $50 \%$ or more of the particles, one or more external dimensions are within the size range of 1-100 nm [110]. Due to their small size and high surface-volume ratio, nanoparticles provide great potential for the food, pharmaceutical and cosmetic industries. However, there is concern about long-term risks related to hard nanomaterials because these insoluble and indecomposable nanoparticles may accumulate in target organs.

The emulsification-evaporation technique is usually applied to prepare stable nanodispersion of astaxanthin. At the first stage, the pigment is solved in a lipophilic organic solvent. The following astaxanthin solvents are routinely used in studies: dimethyl sulfoxide (DMSO), THF, acetone, methanol, ethanol, acetonitrile, dichloromethane and chloroform. They are toxic to humans and need to be removed from the final product. Apart from that, their presence causes the isomerization of all-[E] natural astaxanthin to [Z]-isomeric forms, especially to 9-[Z] and 13-[Z] isomers (Figure 4). In consequence, the color becomes lighter [47].

[Z]-isomers are characterized by lower bioavailability and stability, and they oxidize more rapidly than all-[E]-isomers when exposed to light, oxygen or high temperature. This is important in technological processes, e.g., the feed production process (extrusion) [42]. On the other hand, they exhibit higher anti-oxidative activity than trans isomers, especially 9-[Z]-astaxanthin isomer [18]. Its DPPH scavenging activity, inhibition effect on lipid peroxidation and ROS generation in human neuroblastoma SH-SY5Y cells were higher than of all-trans astaxanthin. The study by Yuan and Chen [111] showed that the degree of isomerization of the pigment depended on the solvent-it was low for DMSO, but chlorinated solvents strongly promoted astaxanthin isomerization, and therefore, they should be avoided. Astaxanthin isomerization increased along with temperature (within the range of $25-50{ }^{\circ} \mathrm{C}$ ). The authors indicated that due to food safety, vegetable oil was the best for the isolation of astaxanthin for nutritional purposes and that the isolation should take place at room temperature. 


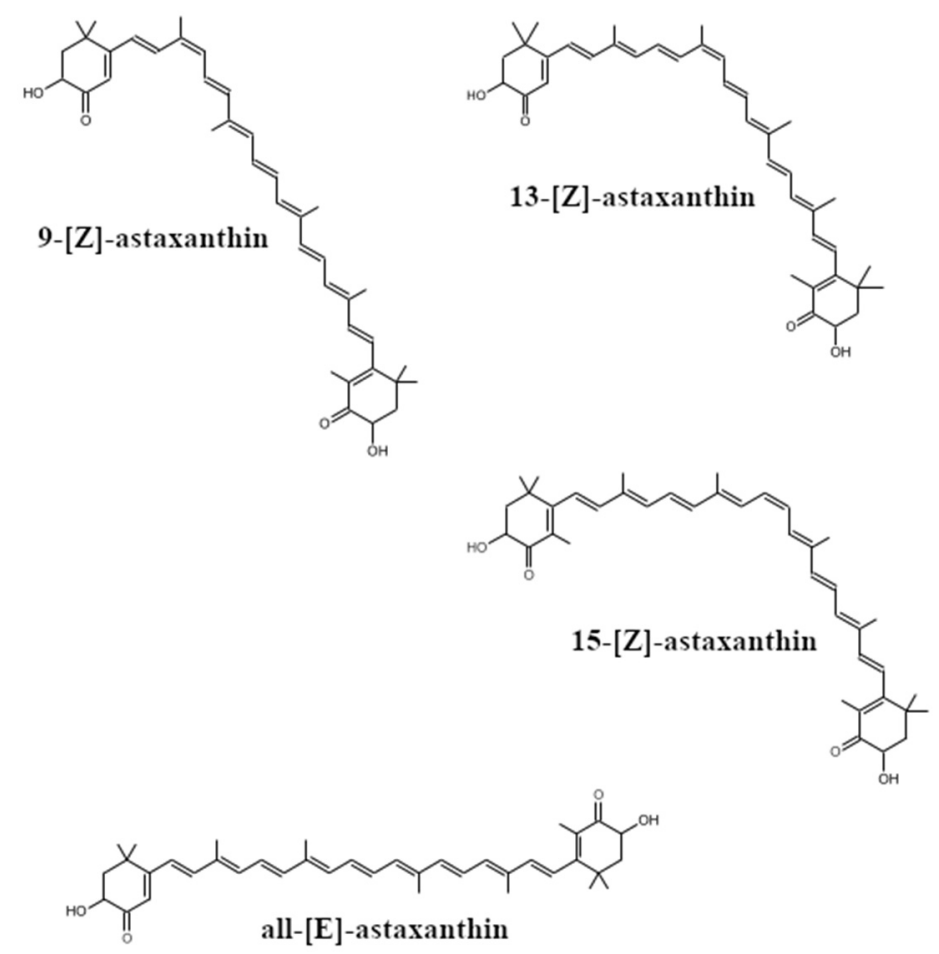

Figure 4. Astaxanthin $\mathrm{E} / \mathrm{Z}$ isomers.

At the next stage, an oil-in-water $(\mathrm{O} / \mathrm{W})$ emulsion is formed by emulsification of the astaxanthin solution with the aqueous phase containing the emulsifier. Then, pigment nanodispersion is achieved in a few cycles by means of high-pressure homogenizers. The lipophilic solvent is subsequently removed from the emulsion by rotary evaporation. Astaxanthin is crystallized in emulsion droplets during evaporation. Different surface-active biopolymers, such as polysaccharides and proteins, instead or with a combination of small molecular emulsifiers, such as lecithin, polysorbates, sugar esters and monoglycerides, can be used to stabilize various nanosized systems. The nature of the stabilizer significantly influences the stability of astaxanthin in prepared nanodispersion systems.

Tachaprutinun et al. [112] used poly(ethylene oxide)-4-methoxycinnamoylphthaloylchitosan (PCPLC) as a stabilizer. It yielded very good encapsulation efficiency (98\%) at loading $40 \%(w / w)$. Moreover, the freeze-dried, astaxanthin-encapsulated PCPLC nanospheres showed good dispersibility in water, yielding stable aqueous suspensions of $300-320 \mathrm{~nm}$ nanoparticles. The thermal stability of astaxanthin in an aqueous environment was greatly improved upon PCPLC nanoencapsulation; i.e., the loss of olefinic functionality, observed when unencapsulated astaxanthin was heated at $70{ }^{\circ} \mathrm{C}$ for two hours, was prevented by PCPLC encapsulation. Ethyl cellulose (EC) and poly(vinylalcohol-covinyl-4-methoxycinnamate) (PB4) were also used as stabilizers. EC was totally inefficient, whereas PB4 exhibited poor encapsulation efficiency. The study showed that successful encapsulation required adequate compatibility between astaxanthin molecules and polymeric nanospheres.

Anarjan and Tan [113] prepared the astaxanthin nanodispersion with optimal physicochemical characteristics and the highest physicochemical stability. They used a threecomponent stabilizer system with $29 \%(w / w)$ polyoxyethylene sorbitan monolaurate, $6 \%(w / w)$ protein-sodium caseinate and $65 \%(w / w)$ polysaccharide-gum arabic. They achieved the maximum chemical stability of the astaxanthin nanodispersion by adding antioxidants, i.e., ascorbic acid and $\alpha$-tocopherol.

Chemically stabilized astaxanthin nanodispersions can be incorporated into food products (such as beverages, soups, spreads), giving them the status of functional foods. The study by Mezquita et al. [114] suggested that astaxanthin oleoresin (AOE) could be 
successfully used to simulate apricot color in skimmed, semi-skimmed and whole milk. During seven-day storage in a domestic refrigerator at a temperature of $5{ }^{\circ} \mathrm{C}$, there were no significant changes in three color coordinates $\mathrm{L}^{*}, \mathrm{a}^{*}$ and $\mathrm{b}^{*}$. This indicated high stability of astaxanthin within the matrix. The water-dispersible emulsion from AOE was used to develop an orange-red color isotonic beverage (IB) with efficient antioxidant action [6]. It showed very good solubility in commercial colorless IBs, giving them an orange-red color, simulating that obtained with a synthetic pigment. However, in prepared PIBP (pigmented isotonic beverage prototype) samples stored at $30^{\circ} \mathrm{C}$ and exposed to light, total degradation of astaxanthin was noted within 7 days. In contrast, in PIBP samples stored in the dark under refrigerated conditions $\left(5 \pm 2{ }^{\circ} \mathrm{C}\right)$, the pigment concentration decreased by $27 \%$ in relation to the initial value during the first week, and by the end of the storage time (91 days), it remained practically unchanged.

Tamjidi et al. [115] incorporated astaxanthin into nanostructured lipid carriers (NLC). $\mathrm{NLC}$ are $\mathrm{O} / \mathrm{W}$ nanoemulsions in which major portions of the lipid phase are solid lipids. High encapsulation efficiency is achieved by effective immobilization of encapsulated lipophilic compounds. This improves their utilization, bioavailability and stability in fat-free and low-fat foods and transparent/opaque beverages. The researchers prepared optimal astaxanthin-NLC formulations consisting of $5 \mathrm{wt} . \%$ lipid phase $(5 \mathrm{mg}$ lecithin as the emulsifier $+20 \mathrm{mg}$ astaxanthin $+975 \mathrm{mg}$ lipids (oleic acid as the liquid lipid and glyceryl behenate as the solid lipid)) and $95 \mathrm{wt} . \%$ aqueous phase (a solution of TWEEN 80 in phosphate buffer solution). Stability tests were carried out for astaxanthin-loaded NLCs (Ax-NLCs) in model beverages: Solutions of sucrose ( $\mathrm{pH} 3.7$ ), semi-actual (whey) and actual (non-alcoholic beer) for a period of 30-60 days storage at 6 or $20^{\circ} \mathrm{C}$ were carried out. It was observed that the presence of sucrose improved the physical stability of AxNLCs in acidic model beverages. In whey, the average size of Ax-NLCs (94 nm) remained unchanged, and no astaxanthin loss was noted. However, carbonation and pasteurization processes of beer samples with NLCs added resulted in an increase in carrier particle size and turbidity as well as astaxanthin loss. Thus, NLCs should be added to $\mathrm{CO}_{2}$-free beverages after pasteurization.

Moreover, the stability tests carried out for $\mathrm{CO}_{2}$-free beers with Ax-NLCs added showed that storage of fortified beer at high temperatures and/or for a long time should be avoided. The desirability of organoleptic attributes of such beers decreased, but they were still acceptable. These results are significant in the context of applicability of nutraceuticalloaded NLCs in food and beverage systems.

\section{Conclusions}

Natural astaxanthin is a bioactive compound whose anti-oxidative activity and healthpromoting properties, resulting from its unique structure, have been well-documented. However, due to its high price and limited sources, it is poorly known to food consumers and underestimated by food producers. For this reason, it is necessary to spread information about this pigment. The anti-oxidative potential of astaxanthin as well as its coloring properties enable food technologists to design a sensorily attractive assortment of functional foods and active packages. The incorporation of astaxanthin into nanodispersion systems is a promising alternative to the use of water-insoluble astaxanthin in water-based food systems.

Haematoccocus pluvialis freshwater algae, Xanthophyllomyces dendrorhous yeasts and crustacean byproducts are natural sources of astaxanthin. Although the cost of natural astaxanthin is high, researchers are conducting extensive investigations to reduce it due to the health-promoting and technological attractiveness of the pigment.

Synthetic astaxanthin is different from natural astaxanthin. It is a mixture of stereoisomers. Some of them are not synthesized in nature, are less stable under technological conditions and have poor bioavailability. EU Regulation (EC) No. 1925/2006 on the addition of vitamins, minerals and other substances to foods does not permit the use of synthetic astaxanthin in food [64]. In the US, it does not have GRAS status, either. Its 
composition is different from the composition of natural astaxanthin. However, no research has indicated that synthetic astaxanthin might be harmful to humans or animals. It is commonly used in the feed industry, especially as a pink and red pigment in aquaculture.

Author Contributions: Conceptualization, writing-original draft preparation, revision and editing of the paper, B.S.; scientific consultation on the concept of the paper and revision of the paper, P.S. All authors have read and agreed to the published version of the manuscript.

Funding: The publication co-financed within the framework of the Polish Ministry of Science and Higher Education's program: "Regional Initiative Excellence" in the years 2019-2022 (No. 005/RID/2018/19)", financing amount 12,000,000 PLN.

Institutional Review Board Statement: Not applicable.

Informed Consent Statement: Not applicable.

Acknowledgments: Many thanks to Krzysztof Dwiecki (Poznan University of Life Sciences, Poland) for a helpful discussion.

Conflicts of Interest: The authors declare no conflict of interest.

\section{References}

1. Olson, J.A. Biological Actions of Carotenoids. J. Nutr. 1989, 119, 94-95. [CrossRef] [PubMed]

2. Lorenz, R.T.; Cysewski, G.R. Commercial Potential for Haematococcus Microalgae as a Natural Source of Astaxanthin. Trends Biotechnol. 2000, 18, 160-167. [CrossRef]

3. Hossain, A.K.M.M.; Brennan, M.A.; Mason, S.L.; Guo, X.; Zeng, X.A.; Brennan, C.S. The Effect of Astaxanthin-Rich Microalgae "Haematococcus Pluvialis" and Wholemeal Flours Incorporation in Improving the Physical and Functional Properties of Cookies. Foods 2017, 6, 57. [CrossRef] [PubMed]

4. Akiba, Y.; Sato, K.; Takahashi, K.; Matsushita, K.; Komiyama, H.; Tsunekawa, H.; Nagao, H. Meat Color Modification in Broiler Chickens by Feeding Yeast Phaffia Rhodozyma Containing High Concentrations of Astaxanthin. J. Appl. Poult. Res. 2001, 10, 154-161. [CrossRef]

5. Anarjan, N.; Tan, C.P. Chemical Stability of Astaxanthin Nanodispersions in Orange Juice and Skimmed Milk as Model Food Systems. Food Chem. 2013, 139, 527-531. [CrossRef] [PubMed]

6. Cerezal Mezquita, P.; Espinosa Álvarez, C.; Palma Ramírez, J.; Bugueño Muñoz, W.; Salinas Fuentes, F.; Ruiz-Domínguez, M.D. Isotonic Beverage Pigmented with Water-Dispersible Emulsion from Astaxanthin Oleoresin. Molecules 2020, 25, 841. [CrossRef] [PubMed]

7. Lim, K.C.; Yusoff, F.M.; Shariff, M.; Kamarudin, M.S. Astaxanthin as Feed Supplement in Aquatic Animals. Rev. Aquac. 2018, 10, 738-773. [CrossRef]

8. Astaxanthin Market Size, Share \& Trends Analysis Report By Source, By Product (Dried Algae Meal, Oil, Softgel), By Application (Nutraceutical, Cosmetics, Aquaculture and Animal Feed), And Segment Forecasts, 2020-2027. In Market Analysis Report; Grand View Research: San Francisco, CA, USA, 2020; p. 76. Available online: https://www.grandviewresearch.com/industry-analysis/ global-astaxanthin-market (accessed on 15 February 2020).

9. Breithaupt, D.E. Modern Application of Xanthophylls in Animal Feeding-A Review. Trends Food Sci. Technol. 2007, 18, 501-506. [CrossRef]

10. Johnson, E.A.; Lewis, M.J. Astaxanthin Formation by the Yeast Phaffia Rhodozyma. J. Gen. Microbiol. 1979, 115, 173-183. [CrossRef]

11. Jacobson, G.K.; Jolly, S.O.; Sedmak, J.J.; Skatrud, T.J.; Wasilewski, J.M. Astaxanthin Over-Producing Strains of Phaffia Rhodozyma, Methods for Their Cultivation and Their Use in Animal Feeds 2000. U.S. Patent No. 6,015,684. Available online: https: / / patentimages.storage.googleapis.com/f5/54/57/1e152be0823090/US6015684.pdf (accessed on 18 January 2000).

12. Guerin, M.; Huntley, M.E.; Olaizola, M. Haematococcus Astaxanthin: Applications for Human Health and Nutrition. Trends Biotechnol. 2003, 21, 210-216. [CrossRef]

13. Lorenz, R.T. A Technical Review of Haematococcus Algae. In NatuRoseTM Tech. Bull.; Cyanotech Corporation: Kailua-Kona, HI, USA, 1999; Volume 60, pp. 1-12.

14. Yamashita, E. Let Astaxanthin Be Thy Medicine. PharmaNutrition 2015, 3, 115-122. [CrossRef]

15. Kishimoto, Y.; Yoshida, H.; Kondo, K. Potential Anti-Atherosclerotic Properties of Astaxanthin. Mar. Drugs 2016, 14, 35. [CrossRef] [PubMed]

16. Goto, S.; Kogure, K.; Abe, K.; Kimata, Y.; Kitahama, K.; Yamashita, E.; Terada, H. Efficient Radical Trapping at the Surface and inside the Phospholipid Membrane Is Responsible for Highly Potent Antiperoxidative Activity of the Carotenoid Astaxanthin. Biochim. Biophys. Acta Biomembr. 2001, 1512, 251-258. [CrossRef]

17. Santocono, M.; Zurria, M.; Berrettini, M.; Fedeli, D.; Falcioni, G. Influence of Astaxanthin, Zeaxanthin and Lutein on DNA Damage and Repair in UVA-Irradiated Cells. J. Photochem. Photobiol. B Biol. 2006, 85, 205-215. [CrossRef] [PubMed] 
18. Liu, X.; Osawa, T. Cis Astaxanthin and Especially 9-Cis Astaxanthin Exhibits a Higher Antioxidant Activity in Vitro Compared to the All-Trans Isomer. Biochem. Biophys. Res. Commun. 2007, 357, 187-193. [CrossRef]

19. Shimidzu, N.; Goto, M.; Miki, W. Carotenoids as Singlet Oxygen Quenchers in Marine Organisms. Fish. Sci. 1996, 62, 134-137. [CrossRef]

20. Chen, Y.-T.; Kao, C.-J.; Huang, H.-Y.; Huang, S.-Y.; Chen, C.-Y.; Lin, Y.-S.; Wen, Z.-H.; Wang, H.-M.D. Astaxanthin Reduces MMP Expressions, Suppresses Cancer Cell Migrations, and Triggers Apoptotic Caspases of In Vitro and In Vivo Models in Melanoma. J. Funct. Foods 2017, 31, 20-31. [CrossRef]

21. Kavitha, K.; Kowshik, J.; Kishore, T.K.K.; Baba, A.B.; Nagini, S. Astaxanthin Inhibits NF-KB and Wnt/ $\beta$-Catenin Signaling Pathways via Inactivation of Erk/MAPK and PI3K/Akt to Induce Intrinsic Apoptosis in a Hamster Model of Oral Cancer. Biochim. Biophys. Acta Gen. Subj. 2013, 1830, 4433-4444. [CrossRef]

22. Che, H.; Li, Q.; Zhang, T.; Wang, D.; Yang, L.; Xu, J.; Yanagita, T.; Xue, C.; Chang, Y.; Wang, Y. Effects of Astaxanthin and Docosahexaenoic-Acid-Acylated Astaxanthin on Alzheimer's Disease in APP/PS1 Double-Transgenic Mice. J. Agric. Food Chem. 2018, 66, 4948-4957. [CrossRef]

23. Grimmig, B.; Daly, L.; Subbarayan, M.; Hudson, C.; Williamson, R.; Nash, K.; Bickford, P.C. Astaxanthin Is Neuroprotective in an Aged Mouse Model of Parkinson's Disease. Oncotarget 2018, 9, 10388-10401. [CrossRef] [PubMed]

24. Park, H.-A.; Hayden, M.M.; Bannerman, S.; Jansen, J.; Crowe-White, K.M. Anti-Apoptotic Effects of Carotenoids in Neurodegeneration. Molecules 2020, 25, 3453. [CrossRef] [PubMed]

25. Capelli, B.; Keily, S.; Cysewski, G.R. The medical research of astaxanthin eye health. In The Medical Research of Astaxanthin; Cyanotech Corporation: Kailua-Kona, HI, USA, 2010; pp. 75-100.

26. Li, H.; Li, J.; Hou, C.; Li, J.; Peng, H.; Wang, Q. The Effect of Astaxanthin on Inflammation in Hyperosmolarity of Experimental Dry Eye Model in Vitro and in Vivo. Exp. Eye Res. 2020, 197, 108113. [CrossRef] [PubMed]

27. Iwamoto, T.; Hosoda, K.; Hirano, R.; Kurata, H.; Matsumoto, A.; Miki, W.; Kamiyama, M.; Itakura, H.; Yamamoto, S.; Kondo, K. Inhibition of Low-Density Lipoprotein Oxidation by Astaxanthin. J. Atheroscler. Thromb. 2000, 7, 216-222. [CrossRef] [PubMed]

28. Mimoun-Benarroch, M.; Lallement, J.; Rhazi, L.; Boroch, C.; Hugot, C.; Niamba, C.-N.; Younes, H.; Depeint, F. Free Form Astaxanthin from Yeast Phaffia Rhodozyma Fermentation Reduces Plasmatic Triglycerides in a Pre-Obesity Diet-Induced Dyslipidaemia Mouse Model. J. Food Compos. Anal. 2018, 65, 11-15. [CrossRef]

29. Fassett, R.G.; Coombes, J.S. Astaxanthin: A Potential Therapeutic Agent in Cardiovascular Disease. Mar. Drugs 2011, 9, 447-465. [CrossRef]

30. Wang, X.; Willén, R.; Wadström, T. Astaxanthin-Rich Algal Meal and Vitamin C Inhibit Helicobacter Pylori Infection in BALB/cA Mice. Antimicrob. Agents Chemother. 2000, 44, 2452-2457. [CrossRef]

31. Kaneko, M.; Kishimoto, Y.; Suzuki, R.; Kawai, Y.; Tateya, I.; Hirano, S. Protective Effect of Astaxanthin on Vocal Fold Injury and Inflammation Due to Vocal Loading: A Clinical Trial. J. Voice 2017, 31, 352-358. [CrossRef]

32. Zhou, L.; Gao, M.; Xiao, Z.; Zhang, J.; Li, X.; Wang, A. Protective Effect of Astaxanthin against Multiple Organ Injury in a Rat Model of Sepsis. J. Surg. Res. 2015, 195, 559-567. [CrossRef]

33. Park, J.; Chyun, J.; Kim, Y.; Line, L.L.; Chew, B.P. Astaxanthin Decreased Oxidative Stress and Inflammation and Enhanced Immune Response in Humans. Nutr. Metab. 2010, 7, 18. [CrossRef]

34. Yasui, Y.; Hosokawa, M.; Mikami, N.; Miyashita, K.; Tanaka, T. Dietary Astaxanthin Inhibits Colitis and Colitis-Associated Colon Carcinogenesis in Mice via Modulation of the Inflammatory Cytokines. Chem. Biol. Interact. 2011, 193, 79-87. [CrossRef] [PubMed]

35. Tominaga, K.; Hongo, N.; Karato, M.; Yamashita, E. Cosmetic Benefits of Astaxanthin on Humans Subjects. Acta Biochim. Pol. 2012, 59. [CrossRef]

36. Scientific Opinion on the Safety of Astaxanthin-Rich Ingredients (AstaREAL A1010 and AstaREAL L10) as Novel Food Ingredients. EFSA J. 2014, 12, 3757. [CrossRef]

37. Buesen, R.; Schulte, S.; Strauss, V.; Treumann, S.; Becker, M.; Gröters, S.; Carvalho, S.; van Ravenzwaay, B. Safety Assessment of [3S, 3'S]-Astaxanthin-Subchronic Toxicity Study in Rats. Food Chem. Toxicol. 2015, 81, 129-136. [CrossRef] [PubMed]

38. Beutner, S.; Bloedorn, B.; Frixel, S.; Hernández Blanco, I.; Hoffmann, T.; Martin, H.-D.; Mayer, B.; Noack, P.; Ruck, C.; Schmidt, M.; et al. Quantitative Assessment of Antioxidant Properties of Natural Colorants and Phytochemicals: Carotenoids, Flavonoids, Phenols and Indigoids. The Role of $\beta$-Carotene in Antioxidant Functions: Antioxidant Properties of Natural Colorants and Phytochemicals. J. Sci. Food Agric. 2001, 81, 559-568. [CrossRef]

39. Jackson, H.; Braun, C.L.; Ernst, H. The Chemistry of Novel Xanthophyll Carotenoids. Am. J. Cardiol. 2008, 101, S50-S57. [CrossRef] [PubMed]

40. Snoeijs, P.; Häubner, N. Astaxanthin Dynamics in Baltic Sea Mesozooplankton Communities. J. Sea Res. 2014, 85, 131-143. [CrossRef]

41. Chayen, N.E.; Cianci, M.; Grossmann, J.G.; Habash, J.; Helliwell, J.R.; Nneji, G.A.; Raftery, J.; Rizkallah, P.J.; Zagalsky, P.F. Unravelling the Structural Chemistry of the Colouration Mechanism in Lobster Shell. Acta Crystallogr. D Biol. Crystallogr. 2003, 59, 2072-2082. [CrossRef]

42. Storebakken, T.; Sørensen, M.; Bjerkeng, B.; Hiu, S. Utilization of Astaxanthin from Red Yeast, Xanthophyllomyces Dendrorhous, in Rainbow Trout, Oncorhynchus Mykiss: Effects of Enzymatic Cell Wall Disruption and Feed Extrusion Temperature. Aquaculture 2004, 236, 391-403. [CrossRef] 
43. Fang, N.; Wang, C.; Liu, X.; Zhao, X.; Liu, Y.; Liu, X.; Du, Y.; Zhang, Z.; Zhang, H. De Novo Synthesis of Astaxanthin: From Organisms to Genes. Trends Food Sci. Technol. 2019, 92, 162-171. [CrossRef]

44. Renstrøm, B.; Berger, H.; Liaaen-Jensen, S. Esterified, Optical Pure (3S, 3'S)-Astaxanthin from Flowers of Adonis Annua. Biochem. Syst. Ecol. 1981, 9, 249-250. [CrossRef]

45. Maoka, T.; Etoh, T.; Kishimoto, S.; Sakata, S. Carotenoids and Their Fatty Acid Esters in the Petals of Adonis Aestivalis. J. Oleo Sci. 2011, 60, 47-52. [CrossRef]

46. Hernández-Becerra, J.A.; Ochoa-Flores, A.A.; Soto-Rodriguez, I.; Rodriguez-Estrada, M.T.; García, H.S. Effect of Cooking Conditions on Cholesterol Oxidation and Astaxanthin in Dried Salted Shrimp: Oxysterols in Cooked Shrimp. Eur. J. Lipid Sci. Technol. 2014, 116, 872-884. [CrossRef]

47. Niamnuy, C.; Devahastin, S.; Soponronnarit, S.; Vijaya Raghavan, G.S. Kinetics of Astaxanthin Degradation and Color Changes of Dried Shrimp during Storage. J. Food Eng. 2008, 87, 591-600. [CrossRef]

48. Liñán-Cabello, M.A.; Paniagua-Michel, J.; Hopkins, P.M. Bioactive Roles of Carotenoids and Retinoids in Crustaceans: Carotenoids and Retinoids in Crustaceans. Acquac. Nutr. 2002, 8, 299-309. [CrossRef]

49. Tsushlma, M.; Kawakami, T.; Mine, M.; Matsuno, T. The Role of Carotenoids in the Development of the Sea Urchin Pseudocentrotus Depressus. Invertebr. Reprod. Dev. 1997, 32, 149-153. [CrossRef]

50. Haijima, Y.; Karino, K. Algal-Diet Enhances Sexual Ornament, Growth And Reproduction in the Guppy. Behaviour 2004, 141, 585-601. [CrossRef]

51. Ahmadi, M.R.; Bazyar, A.A.; Safi, S.; Ytrestøyl, T.; Bjerkeng, B. Effects of Dietary Astaxanthin Supplementation on Reproductive Characteristics of Rainbow Trout (Oncorhynchus Mykis). J. Appl. Ichthyol. 2006, 22, 388-394. [CrossRef]

52. Dansou, D.M.; Wang, H.; Nugroho, R.D.; He, W.; Zhao, Q.; Zhang, J. Assessment of Response to Moderate and High Dose Supplementation of Astaxanthin in Laying Hens. Animals 2021, 11, 1138. [CrossRef] [PubMed]

53. Ausich, R.L. Commercial Opportunities for Carotenoid Production by Biotechnology. Pure Appl. Chem. 1997, 69, 2169-2174. [CrossRef]

54. Rodríguez-Sáiz, M.; de la Fuente, J.L.; Barredo, J.L. Xanthophyllomyces Dendrorhous for the Industrial Production of Astaxanthin. Appl. Microbiol. Biotechnol. 2010, 88, 645-658. [CrossRef]

55. Panis, G.; Carreon, J.R. Commercial Astaxanthin Production Derived by Green Alga Haematococcus Pluvialis: A Microalgae Process Model and a Techno-Economic Assessment All through Production Line. Algal Res. 2016, 18, 175-190. [CrossRef]

56. Calo, P.; Velazquez, J.B.; Sieiro, C.; Blanco, P.; Longo, E.; Villa, T.G. Analysis of Astaxanthin and Other Carotenoids from Several Phaffia RhodozymaMutants. J. Agric. Food Chem. 1995, 43, 1396-1399. [CrossRef]

57. Yuan, J.-P.; Chen, F. Kinetics for the Reversible Isomerization Reaction of Trans-Astaxanthin. Food Chem. 2001, 73, 131-137. [CrossRef]

58. Widmer, E.; Zell, R.; Broger, E.A.; Crameri, Y.; Wagner, H.P.; Dinkel, J.; Schlageter, M.; Lukáč, T. Technische Verfahren Zur Synthese von Carotinoiden Und Verwandten Verbindungen Aus 6-Oxo-Isophoron. II. Ein Neues Konzept Für Die Synthese von (3RS, 3'RS )-Astaxanthin. Helv. Chim. Acta 1981, 64, 2436-2446. [CrossRef]

59. Nguyen, K.D. Astaxanthin: Comperative Case of Synthetic vs. Natural Production. TRACE Faculty Publications and Other Works_Chemical and Biomolecular Engineering. 2013. Available online: http://trace.tennessee.edu/utk_chembiopubs/94 (accessed on 8 May 2013).

60. Fang, T.J.; Chiou, T.-Y. Batch Cultivation and Astaxanthin Production by a Mutant of the Red Yeast Phaffia Rhodozyma NCHU-FS501. J. Ind. Microbiol. 1996, 16, 175-181. [CrossRef]

61. Commission Implementing Regulation (EU) 2015/1415 of 20 August 2015 Concerning the Authorisation of Astaxanthin as a Feed Additive for Fish, Crustaceans and Ornamental Fish. OJEU 2015, L 220, 7-10. Available online: https:/ / eur-lex.europa.eu/eli/ reg_impl/2015/1415/oj (accessed on 21 August 2015).

62. Commission Regulation (EC) No 393/2008 of 30 April 2008 Concerning the Authorisation of Astaxanthin Dimethyldisuccinate as a Feed Additive. OJEU 2008, L 117, 20-21. Available online: http:/ / data.europa.eu/eli/reg/2008/393/oj (accessed on 1 May 2008).

63. Commission Implementing Regulation (EU) 2020/998 of 9 July 2020 Concerning the Renewal of the Authorisation of AstaxanthinDimethyldisuccinate as a Feed Additive for Fish and Crustaceans and Repealing Regulation (EC) No 393/2008. OJEU 2020, L 221, 96-98. Available online: https:/ / eur-lex.europa.eu/eli/reg_impl/2020/998/oj (accessed on 10 July 2020).

64. Regulation (EC) No 1925/2006 of the European Parliament and of the Council of 20 December 2006 on the Addition of Vitamins and Minerals and of Certain Other Substances to Foods. OJEU 2006, L 404, 26-38. Available online: http:/ / data.europa.eu/ eli/ reg/2006/1925/oj (accessed on 30 December 2006).

65. Villalobos-Castillejos, F.; Cerezal-Mezquita, P.; Hernández-De Jesús, M.L.; Barragán-Huerta, B.E. Production and Stability of Water-Dispersible Astaxanthin Oleoresin from Phaffia Rhodozyma. Int. J. Food Sci. Technol. 2013, 48, 1243-1251. [CrossRef]

66. Yuan, J.-P.; Chen, F.; Liu, X.; Li, X.-Z. Carotenoid Composition in the Green Microalga Chlorococcum. Food Chem. 2002, 76, 319-325. [CrossRef]

67. Bhosale, P.; Bernstein, P.S. Microbial Xanthophylls. Appl. Microbiol. Biotechnol. 2005, 68, 445-455. [CrossRef]

68. Cunningham, F.X.; Gantt, E. A Portfolio of Plasmids for Identification and Analysis of Carotenoid Pathway Enzymes: Adonis Aestivalis as a Case Study. Photosynth. Res. 2007, 92, 245-259. [CrossRef] 
69. Gwak, Y.; Hwang, Y.; Wang, B.; Kim, M.; Jeong, J.; Lee, C.-G.; Hu, Q.; Han, D.; Jin, E. Comparative Analyses of Lipidomes and Transcriptomes Reveal a Concerted Action of Multiple Defensive Systems against Photooxidative Stress in Haematococcus Pluvialis. J. Exp. Bot. 2014, 65, 4317-4334. [CrossRef]

70. Mawson, R. Astaxanthin from Flowers of the Genus Adonis Patent US5453565A. 1995. Available online: https:/ / patents.google. $\mathrm{com} /$ patent/US5453565A/en (accessed on 26 September 1995).

71. Cunningham, F.X. Carotenoid Ketolase Genes and Gene Products, Production of Ketocarotenoids and Methods of Modifying Carotenoids Using the Genes Patent US6551807B1. 2003. Available online: https://patents.google.com/patent/US6551807 (accessed on 22 April 2003).

72. Cunningham, F.X.; Gantt, E. A Study in Scarlet: Enzymes of Ketocarotenoid Biosynthesis in the Flowers of Adonis Aestivalis: Adonis $\beta$-Ring Oxygenases. Plant J. 2005, 41, 478-492. [CrossRef] [PubMed]

73. Cunningham, F.X.; Chase, C. Biochemical Route to Astaxanthin Patent US20070157339A1. 2007. Available online: https: / / patents.google.com/patent/US20070157339 (accessed on 5 July 2007).

74. Huang, J.-C.; Zhong, Y.-J.; Liu, J.; Sandmann, G.; Chen, F. Metabolic Engineering of Tomato for High-Yield Production of Astaxanthin. Metab. Eng. 2013, 17, 59-67. [CrossRef] [PubMed]

75. Flachmann, R.; Klebsattel, M.; Luck, T.; Pfeiffer, A.-M.; Sauer, M.; Schopfer, C.R.; Voeste, D. Use of Astaxanthin-Containing Plants or Parts of Plants of the Genus Tagetes Patent AU2003264062B2. 2008. Available online: https://patents.google.com/patent/ AU2003264062B2/en (accessed on 3 January 2008).

76. Tuli, H.S.; Chaudhary, P.; Beniwal, V.; Sharma, A.K. Microbial Pigments as Natural Color Sources: Current Trends and Future Perspectives. J. Food Sci. Technol. 2015, 52, 4669-4678. [CrossRef]

77. Ranjbar, R.; Inoue, R.; Katsuda, T.; Yamaji, H.; Katoh, S. High Efficiency Production of Astaxanthin in an Airlift Photobioreactor. J. Biosci. Bioeng. 2008, 106, 204-207. [CrossRef] [PubMed]

78. Gao, Z.; Meng, C.; Zhang, X.; Xu, D.; Miao, X.; Wang, Y.; Yang, L.; Lv, H.; Chen, L.; Ye, N. Induction of Salicylic Acid (SA) on Transcriptional Expression of Eight Carotenoid Genes and Astaxanthin Accumulation in Haematococcus Pluvialis. Enzym. Microb. Technol. 2012, 51, 225-230. [CrossRef]

79. Wen, Z.; Liu, Z.; Hou, Y.; Liu, C.; Gao, F.; Zheng, Y.; Chen, F. Ethanol Induced Astaxanthin Accumulation and Transcriptional Expression of Carotenogenic Genes in Haematococcus Pluvialis. Enzym. Microb. Technol. 2015, 78, 10-17. [CrossRef] [PubMed]

80. Dufossé, L.; Galaup, P.; Yaron, A.; Arad, S.M.; Blanc, P.; Chidambara Murthy, K.N.; Ravishankar, G.A. Microorganisms and Microalgae as Sources of Pigments for Food Use: A Scientific Oddity or an Industrial Reality? Trends Food Sci. Technol. 2005, 16, 389-406. [CrossRef]

81. Commission Implementing Regulation (EU) 2017/2470 of 20 December 2017 Establishing the Union List of Novel Foods in Accordance with Regulation (EU) 2015/2283 of the European Parliament and of the Council on Novel Foods. OJEU 2017, L 351, 72-201. Available online: https:/ / eur-lex.europa.eu/eli/reg_impl/2017/2470/oj (accessed on 30 December 2017).

82. Flen, B.; Christensen, I.; Larsen, R.; Johansen, S.R.; Johnson, E.A. Astaxanthin-Producing Yeast Cells, Methods for Their Preparation and Their Use Patent EP0367765B2. 2004. Available online: https:// patentimages.storage.googleapis.com/b8/b4/a0 /a6cae586a0456c/EP0367765B2.pdf (accessed on 28 April 2004).

83. White, D.A.; Page, G.I.; Swaile, J.; Moody, A.J.; Davies, S.J. Effect of Esterification on the Absorption of Astaxanthin in Rainbow Trout, Oncorhynchus Mykiss (Walbaum): Absorption of Astaxanthin by Rainbow Trout. Aquac. Res. 2002, 33, 343-350. [CrossRef]

84. An, G.-H.; Schuman, D.B.; Johnson, E.A. Isolation of Phaffia Rhodozyma Mutants with Increased Astaxanthin Content. Appl. Environ. Microbiol. 1989, 55, 116-124. [CrossRef]

85. Stachowiak, B. Astaxanthin Synthesis by Xanthophyllomyces Dendrorhous DSM 5626 and Its Astaxanthin Overproducing Mutants on Xylose Media under Diferent Illumination. Acta Sci. Pol. Technol. Aliment. 2014, 13, 279-288. [CrossRef]

86. Schmidt, I.; Schewe, H.; Gassel, S.; Jin, C.; Buckingham, J.; Hümbelin, M.; Sandmann, G.; Schrader, J. Biotechnological Production of Astaxanthin with Phaffia Rhodozyma/Xanthophyllomyces Dendrorhous. Appl. Microbiol. Biotechnol. 2011, 89, 555-571. [CrossRef]

87. Gassel, S.; Breitenbach, J.; Sandmann, G. Genetic Engineering of the Complete Carotenoid Pathway towards Enhanced Astaxanthin Formation in Xanthophyllomyces Dendrorhous Starting from a High-Yield Mutant. Appl. Microbiol. Biotechnol. 2014, 98, 345-350. [CrossRef] [PubMed]

88. Wan, X.; Zhou, X.-R.; Moncalian, G.; Su, L.; Chen, W.-C.; Zhu, H.-Z.; Chen, D.; Gong, Y.-M.; Huang, F.-H.; Deng, Q.-C. Reprogramming Microorganisms for the Biosynthesis of Astaxanthin via Metabolic Engineering. Prog. Lipid Res. $2021,81,101083$. [CrossRef]

89. Mezzomo, N.; Maestri, B.; dos Santos, R.L.; Maraschin, M.; Ferreira, S.R.S. Pink Shrimp (P. Brasiliensis and P. Paulensis) Residue: Influence of Extraction Method on Carotenoid Concentration. Talanta 2011, 85, 1383-1391. [CrossRef]

90. Sánchez-Camargo, A.P.; Martinez-Correa, H.A.; Paviani, L.C.; Cabral, F.A. Supercritical CO2 Extraction of Lipids and Astaxanthin from Brazilian Redspotted Shrimp Waste (Farfantepenaeus Paulensis). J. Supercrit. Fluids 2011, 56, 164-173. [CrossRef]

91. Pu, J.; Bechtel, P.J.; Sathivel, S. Extraction of Shrimp Astaxanthin with Flaxseed Oil: Effects on Lipid Oxidation and Astaxanthin Degradation Rates. Biosyst. Eng. 2010, 107, 364-371. [CrossRef]

92. Sachindra, N.M.; Mahendrakar, N.S. Process Optimization for Extraction of Carotenoids from Shrimp Waste with Vegetable Oils. Bioresour. Technol. 2005, 96, 1195-1200. [CrossRef] [PubMed]

93. Hu, J.; Lu, W.; Lv, M.; Wang, Y.; Ding, R.; Wang, L. Extraction and Purification of Astaxanthin from Shrimp Shells and the Effects of Different Treatments on Its Content. Rev. Bras. Farm. 2019, 29, 24-29. [CrossRef] 
94. Durante, M.; Lenucci, M.S.; Marrese, P.P.; Rizzi, V.; De Caroli, M.; Piro, G.; Fini, P.; Russo, G.L.; Mita, G. $\alpha$-Cyclodextrin Encapsulation of Supercritical CO2 Extracted Oleoresins from Different Plant Matrices: A Stability Study. Food Chem. 2016, 199, 684-693. [CrossRef]

95. Uwineza, P.A.; Waśkiewicz, A. Recent Advances in Supercritical Fluid Extraction of Natural Bioactive Compounds from Natural Plant Materials. Molecules 2020, 25, 3847. [CrossRef]

96. Sachindra, N.M.; Bhaskar, N.; Mahendrakar, N.S. Recovery of Carotenoids from Shrimp Waste in Organic Solvents. Waste Manag. 2006, 26, 1092-1098. [CrossRef] [PubMed]

97. Chen, X.; Chen, R.; Guo, Z.; Li, C.; Li, P. The Preparation and Stability of the Inclusion Complex of Astaxanthin with $\beta$-Cyclodextrin. Food Chem. 2007, 101, 1580-1584. [CrossRef]

98. Tan, C.; Nakajima, M. ß-Carotene Nanodispersions: Preparation, Characterization and Stability Evaluation. Food Chem. 2005, 92, 661-671. [CrossRef]

99. Hix, L.M.; Frey, D.A.; McLaws, M.D.; Østerlie, M.; Lockwood, S.F.; Bertram, J.S. Inhibition of Chemically-Induced Neoplastic Transformation by a Novel Tetrasodium Diphosphate Astaxanthin Derivative. Carcinogenesis 2005, 26, 1634-1641. [CrossRef]

100. Lockwood, S.F.; Gross, G.J. Disodium Disuccinate Astaxanthin (CardaxTM): Antioxidant and Antiinflammatory Cardioprotection. Cardiovasc. Drug Rev. 2006, 23, 199-216. [CrossRef] [PubMed]

101. Lockwood, S.F.; O’Malley, S.; Mosher, G.L. Improved Aqueous Solubility of Crystalline Astaxanthin (3,3'-dihydroxy- $\beta$, B-carotene4,4'-dione) by Captisol ${ }^{\circledR}$ (Sulfobutyl Ether B-Cyclodextrin). J. Pharm. Sci. 2003, 92, 922-926. [CrossRef]

102. Anarjan, N.; Mirhosseini, H.; Baharin, B.S.; Tan, C.P. Effect of Processing Conditions on Physicochemical Properties of Sodium Caseinate-Stabilized Astaxanthin Nanodispersions. LWT 2011, 44, 1658-1665. [CrossRef]

103. Shen, Q.; Quek, S.Y. Microencapsulation of Astaxanthin with Blends of Milk Protein and Fiber by Spray Drying. J. Food Eng. 2014, 123, 165-171. [CrossRef]

104. Higuera-Ciapara, I.; Félix-Valenzuela, L.; Goycoolea, F.M. Astaxanthin: A Review of Its Chemistry and Applications. Crit. Rev. Food Sci. Nutr. 2006, 46, 185-196. [CrossRef]

105. Durante, M.; Milano, F.; Caroli, M.D.; Giotta, L.; Piro, G.; Mita, G.; Frigione, M.; Lenucci, M.S. Tomato Oil Encapsulation by $\alpha-, \beta-$, and $\gamma$-Cyclodextrins: A Comparative Study on the Formation of Supramolecular Structures, Antioxidant Activity, and Carotenoid Stability. Foods 2020, 9, 1553. [CrossRef] [PubMed]

106. Yuan, C.; Du, L.; Jin, Z.; Xu, X. Storage Stability and Antioxidant Activity of Complex of Astaxanthin with Hydroxypropyl- $\beta$ Cyclodextrin. Carbohydr. Polym. 2013, 91, 385-389. [CrossRef]

107. Lancrajan, I.; Diehl, H.A.; Socaciu, C.; Engelke, M.; Zorn-Kruppa, M. Carotenoid Incorporation into Natural Membranes from Artificial Carriers: Liposomes and $\beta$-Cyclodextrins. Chem. Phys. Lipids 2001, 112, 1-10. [CrossRef]

108. Ribeiro, H.S.; Ax, K.; Schubert, H. Stability of Lycopene Emulsions in Food Systems. J. Food Sci. 2003, 68, 2730-2734. [CrossRef]

109. Dos Santos, P.P.; de Aguiar Andrade, L.; Flôres, S.H.; de Oliveira Rios, A. Nanoencapsulation of Carotenoids: A Focus on Different Delivery Systems and Evaluation Parameters. J. Food Sci. Technol. 2018, 55, 3851-3860. [CrossRef]

110. Commission Recommendation of 18 October 2011 on the Definition of Nanomaterial. OJEU 2011, L 275, 38-40. Available online: http:/ / data.europa.eu/eli/reco/2011/696/oj (accessed on 20 October 2011).

111. Yuan, J.-P.; Chen, F. Isomerization of Trans-Astaxanthin to Cis-Isomers in Organic Solvents. J. Agric. Food Chem. 1999, 47, 3656-3660. [CrossRef] [PubMed]

112. Tachaprutinun, A.; Udomsup, T.; Luadthong, C.; Wanichwecharungruang, S. Preventing the Thermal Degradation of Astaxanthin through Nanoencapsulation. Int. J. Pharm. 2009, 374, 119-124. [CrossRef] [PubMed]

113. Anarjan, N.; Tan, C.P. Effects of Storage Temperature, Atmosphere and Light on Chemical Stability of Astaxanthin Nanodispersions. J. Am. Oil Chem. Soc. 2013, 90, 1223-1227. [CrossRef]

114. Mezquita, P.C.; Huerta, B.E.B.; Ramírez, J.C.P.; Hinojosa, C.P.O. Milks Pigmentation with Astaxanthin and Determination of Colour Stability during Short Period Cold Storage. J. Food Sci. Technol. 2015, 52, 1634-1641. [CrossRef] [PubMed]

115. Tamjidi, F.; Shahedi, M.; Varshosaz, J.; Nasirpour, A. Stability of Astaxanthin-loaded Nanostructured Lipid Carriers in Beverage Systems. J. Sci. Food Agric. 2018, 98, 511-518. [CrossRef] [PubMed] 